Agroforestry Education in the Philippines:

Status Report from the Southeast Asian

Network for Agroforestry Education

Leila Landicho and Jesus C. Fernandez 



\section{Agroforestry Education in the Philippines: Status Report from the Southeast Asian Network for Agroforestry Education (SEANAFE)}

Leila Landicho ${ }^{1}$ and Jesus C. Fernandez ${ }^{2}$

Working Paper nr 96

\footnotetext{
${ }^{1}$ University Research Associate II at the Institute of Agroforestry-College of Forestry and Natural Resources, University of the Philippines Los Bano; Email: leila landicho@yahoo.com

${ }^{2}$ ICRAF Capacity Building Specialist and SEANAFE Technical Adviser, E-mail: j.c.fernandez@cgiar.org
} 


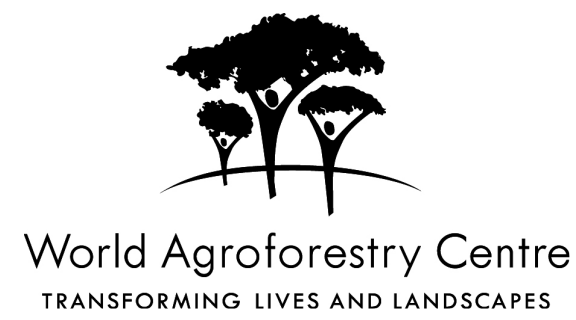

\section{Correct citation:}

Leila Landicho and Jesus C. Fernandez. 2009. Agroforestry Education in the Philippines:

Status Report from the Southeast Asian Network for Agroforestry Education (SEANAFE). Working paper 96.

World Agroforestry Centre. Bogor, Indonesia. 23p

Titles in the Working Paper Series aim to disseminate interim results on agroforestry research and practices and stimulate feedback from the scientific community. Other publication series from the World Agroforestry Centre include: Agroforestry Perspectives, Technical Manuals and Occasional Papers.

Published by

World Agroforestry Centre

ICRAF Southeast Asia Regional Office

PO Box 161, Bogor 16001, Indonesia

Tel: +622518625415

Fax: +62 2518625416

Email: icraf-indonesia@cgiar.org

http://www.worldagroforestrycentre.org/sea

(C) World Agroforestry Centre 2009

Working Paper nr 96

The views expressed in this publication are those of the author(s) and not necessarily those of the World Agroforestry Centre.

Articles appearing in this publication may be quoted or reproduced without charge, provided the source is acknowledged.

All images remain the sole property of their source and may not be used for any purpose without written permission of the source. 


\section{About the authors}

Ms. Leila D. Landicho is a University Research Associate II at the Institute of Agroforestry-College of Forestry and Natural Resources, University of the Philippines Los Banos. She also serves as the Secretary of the Philippine Agroforestry Education and Research Network (PAFERN).

Dr. Jesus C. Fernandez is currently serving as Capacity Building Specialist at the World Agroforestry Centre (ICRAF) Southeast Asia Regional Office in Indonesia and as Technical Adviser of the Southeast Asia Network for Agroforestry Education (SEANAFE). His tasks mainly involve curriculum and teaching materials development, organizing and implementing capacity building activities for university teachers and administrators, and agroforestry education advocacy 


\section{Preface}

The Southeast Asian Network for Agroforestry Education (SEANAFE) is a network of 94 academic institutions in Indonesia, Laos, Malaysia, Philippines, Thailand, and Vietnam. Since its establishment in 1999, SEANAFE's mission has been to 'help improve agroforestry education, training, research and extension, and contribute to socioeconomic development, empowerment of farming communities and sustainable natural resources and environmental management in the Southeast Asian region.'

SEANAFE's 2006 impact study on agroforestry education capacity revealed significant improvements among its member institutions across countries though they vary in status. In most countries, agroforestry has remained as a course offering in either BS Agriculture or BS Forestry programs. In the Philippines, however, agroforestry is being taught as either a major field of study or a full BS degree program in 34 and 11 member institutions of SEANAFE, respectively. The differences may be brought about by each county's agriculture, environmental and educational policies and priorities, and job markets. SEANAFE welcomes such diversity. But at the same time, SEANAFE continues to work in providing common opportunities and experiences among its member institutions in the hope of achieving some degree of standardization in agroforestry curricular and teaching material contents within a regional context.

Recently, agroforestry has assumed new roles in relation to current global economic development and environmental concerns. SEANAFE believes that learning institutions play a critical role in this situation by providing more responsive program offerings and services in agroforestry education. SEANAFE further believes that continuous improvements in agroforestry education could only happen if learning institutions have full knowledge of their status and needs. This report is an attempt toward this end with special focus on the Philippines.

SEANAFE plans to come up with similar reports for the rest of its member countries soon. Being the first, this report also desires to stimulate further discussions and interest among SEANAFE member institutions as well as other organizations in the region, to share their ideas and experiences in making agroforestry more appealing to students and other stakeholders. Clearly, agroforestry has much to contribute to the development and conservation of the region's uplands. But the region needs more human resources to transform this huge potential into a reality. Works like this report, hopefully, could contribute toward the fulfillment of this desire.

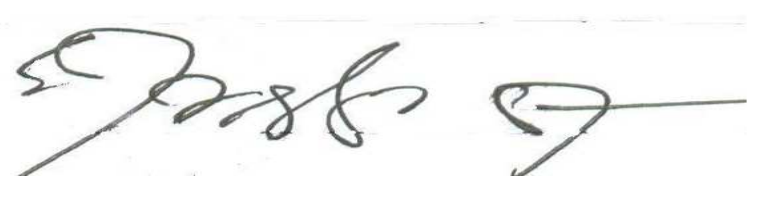

Dr. Wilfredo M. Carandang

SEANAFE Board Chair 


\section{Abstract}

This paper is based on the survey data collected by the Southeast Asian Network for Agroforestry Education (SEANAFE) from 22 out of 34 member institutions of the Philippine Agroforestry Education and Research Network (PAFERN) between 2007 and 2008. The survey was also intended to help PAFERN and SEANAFE identify future projects and activities relevant to accomplishing SEANAFE's vision-mission of improving livelihoods and ensuring sustainable rural development in the region through improved agroforestry education.

The survey results indicated a significant growth in agroforestry education in the Philippines since 1976 because of the perceived need to continuously produce manpower to help rehabilitate the upland areas. Currently, there are already 34 academic institutions offering different types of agroforestry programs in the country. These programs include BS Agriculture major in Agroforestry (BSA-AF), BS Forestry major in Agroforestry (BSF-AF), BS Agroforestry (BSAF), BS Agroforestry Entrepreneurship (BSAE), terminal and ladderized Diploma/Certificate in Agroforestry, and Master of Science in Agroforestry (MSAF).

The past two decades have also shown considerable improvements in the qualifications of teaching staff in academic institutions offering BSAF program. Teaching materials, though limited in number, were always made available to students. The Policy, Standards and Guidelines (PSG) for BSAF issued by the Philippine Commission on Higher Education (CHED) in 2006 has helped standardize the curriculum for the said program among institutions surveyed. Nevertheless, agroforestry courses were still being taught in other related programs. While interest to conduct research and extension activities among faculty was increasing, opportunities were nevertheless limited for them due to resource constraints and heavy workload. On the other hand, students' interest to pursue a BSAF degree was observed to be declining due to limited job prospects after graduation. Incidents of drop out among BSAF students were also occurring in most academic institutions because of financial constraints.

There is a need for academic institutions and agroforestry networks, such as PAFERN and the National Association of Agroforesters of the Philippines (NAAP), to establish more innovative recruitment, curricular review, and job placement programs to make agroforestry education more attractive to students and prospective employers. PAFERN and NAAP should also take the lead to lobby with the local government units (LGUs) to create core positions for agroforestry graduates and provide financial support to implement collaborative agroforestry research and extension programs for rural development with learning institutions. A database of essential agroforestry teaching materials and facilities available in the country would facilitate effective and efficient sharing of the same among the learning institutions and ensure the quality of teaching agroforestry to students.

\section{Keywords:}

agroforestry education, status, assessment, Philippines 


\section{Acknowledgement}

The authors acknowledge the following that contributed to the publication of this ICRAF working paper:

- The Swedish International Development Cooperation Agency (Sida) for the funding support to carry out the assessment survey on agroforestry eduction in the Philippines.

- The member-institutions of the Philippine Agroforestry Education and Research Network (PAFERN) that served as survey respondents.

- The PAFERN Secretariat for providing assistance in the follow-up of the survey respondents.

- The World Agroforestry Centre (ICRAF) for providing the venue to publish the survey results.

- Mr. Andrew Warner for editing this working paper. 


\section{Contents}

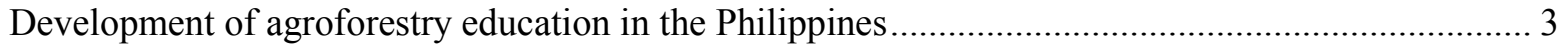

Milestones in the development of agroforestry education programs in the Philippines ....................... 5

Variants of agroforestry curricular programs in the Philippines......................................................... 7

Agroforestry curriculum development process in the Philippines .................................................... 9

Enrolment and students' performance in agroforestry education programs .................................... 11

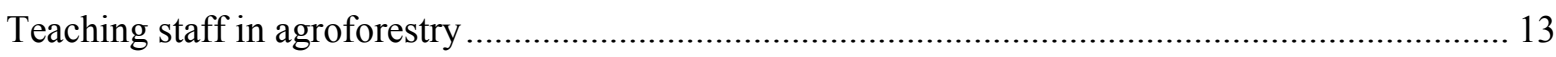

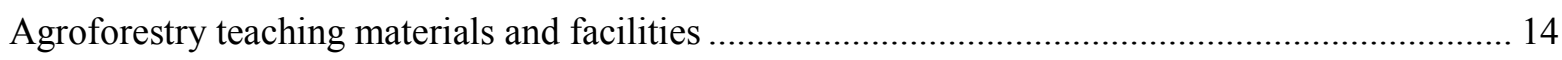

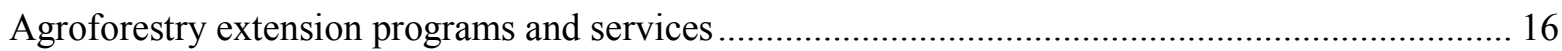

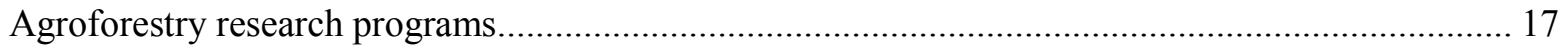

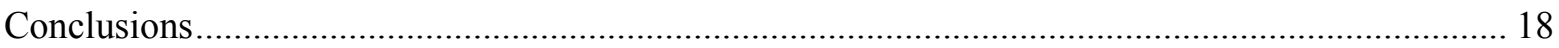

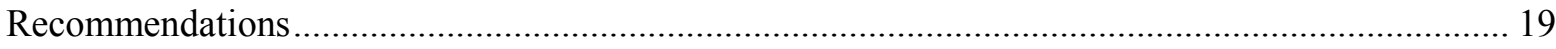

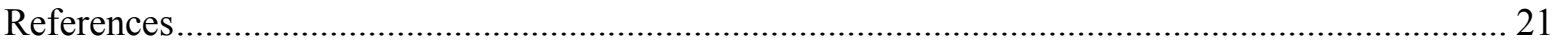




\section{List of Figures}

Figure 1. Geographical distribution of PAFERN institutions engaged in agroforestry education programs ......

Figure 2. Classification of academic institutions engaged in agroforestry education programs............ 3

Figure 3. Rate of completion of baccalaureate/undergraduate degree among BSAF students........... 12

Figure 4a. Adequacy of agroforestry teaching materials and facilities in the surveyed institutions.... 14

Figure 4b. Availability of agroforestry teaching materials and facilities in the surveyed institutions.. 15

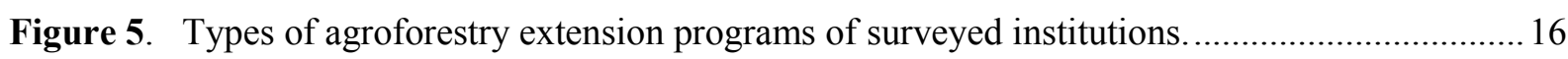

\section{List of Tables}

Table 1. Reasons for the implementation of agroforestry curricular programs in the Philippines...... 4

Table 2. Variants of agroforestry curricular programs in the Philippines......................................... 7

Table 3. Other schemes by which the teaching of agroforestry is integrated in other degree programs and courses in the Philippines....................................................................... 8

Table 4. Number of institutions offering agroforestry education programs by base

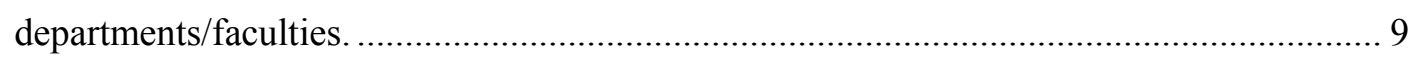

Table 5. Number of institutions that conducted agroforestry curricular reviews per type of program from 1995 to 2007.

Table 6. Strategies in agroforestry curriculum development and review........................................ 10

Table 7. Observed enrolment trend in agroforestry education programs........................................ 11

Table 8. Profile of teaching staff involved in the agroforestry education programs........................ 13

Table 9. Status of agroforestry research in the surveyed institutions............................................. 17 


\section{Acronyms}

BSAF Bachelor of Science in Agroforestry

BSA-AF Bachelor of Science in Agriculture major in Agroforestry

BSF-AF Bachelor of Science in Forestry major in Agroforestry

BAFT Bachelor in Agroforestry Technology

BAFE Bachelor in Agroforestry Entrepreneurship

BSAFE Bachelor of Science in Agroforestry Entrepreneurship

CHED Commission on Higher Education

DAF Diploma in Agroforestry

DAFT Diploma in Agroforestry Technology

DMMMSU Don Mariano Marcos Memorial State University

ICRAF World Agroforestry Centre (formerly International Centre for Research in Agroforestry)

LGUs Local Government Units

MAFTP Markets for Agroforestry Tree Products

MSAF Master of Science in Agroforestry

NAAP National Agroforesters' Association of the Philippines

PAFERN Philippine Agroforestry Education and Research Network

PSG Policy, Standards and Guidelines

SCU State colleges and universities

SEANAFE Southeast Asian Network for Agroforestry Education

Sida Swedish International Development Cooperation Agency

TESDA Technical Skills and Development Authority

UPLB-IAF University of the Philippines Los Banos-Institute of Agroforestry 


\section{Introduction}

Agroforestry education has gone a long way in the Philippines. From a single institution that offered Bachelor of Science in Agroforestry (BASF) in 1976, the number has now grown to 34 and may continue to grow with the emerging new roles and the renewed interest on agroforestry in addressing global economic and environmental concerns.

The mounting interest to implement agroforestry education program in the Philippines was observed in the mid-90s. During this period, participation of state colleges and universities in short-term training courses in agroforestry increased particularly in courses offered by the University of the Philippines Los Banos Agroforestry Program (UAP), now the UPLB Institute of Agroforestry (UPLBIAF).

The 1995 UPLB-IAF Agroforestry Education Needs Assessment funded by the Ford Foundation revealed that there were 18 academic institutions already implementing agroforestry education programs in the Philippines. At that time, only three types of programs existed at the baccalaureate level, namely: BS Agriculture major in Agroforestry (BSA-AF), BS Forestry major in Agroforestry (BSF-AF) and BS Agroforestry (BSAF). The minimum standards being used for the BSA-AF and BSF-AF were considered outdated while none was existing yet for the BSAF.

In 1998, the International Centre for Research in Agriculture (ICRAF), renamed as World Agroforestry Centre, through its Southeast Asia Regional Office, also commissioned a status and needs assessment study of agroforestry education in the Philippines, Indonesia, Thailand, Lao PDR and Vietnam. This study found out that there were a number of development issues and needs confronting academic institutions across countries offering various agroforestry curricula in the region. Among the relevant issues and needs identified included the lack of minimum standards and guiding principles in offering agroforestry programs; limited opportunities for staff development; shortage of teaching materials; and limited capacities to undertake research in agroforestry (Rudebjer and Del Castillo, 1998).

In the Philippines, the 1998 ICRAF study indicated that most of the 26 agroforestry schools surveyed expressed an urgent need for staff development in agroforestry. This was attributed to the fact that at the time of the study, the number and levels of education of the teaching staff were lower than they had hoped to have. Most schools have also expressed the need for a curricular guide that they could use in developing their agroforestry curricula, particularly on the BSAF. A number of schools were also lacking in agroforestry reference materials, including the classroom and field laboratories. While these institutions are mandated to do research and extension activities, the lack of research funds and the limited staff capacity have constrained a number of them to implement responsive research and development programs. It is very interesting to note, however, that student recruitment and enrolment in various agroforestry curricula was on the increasing trend in 1998. On the average, student enrolment was 128 students per school at the undergraduate level. In fact, most of these schools then had more students than they could effectively handle.

These studies triggered the establishment of the Southeast Asian Network for Agroforestry Education (SEANAFE) in 1999 with funding support from the Swedish International Development Cooperation Agency (Sida). The regional network was formed primarily to help strengthen the quality of agroforestry education in the region. Among the priority activities of SEANAFE include: a) review and development of agroforestry curricula; b) teaching materials supply, development and translation; c) facilitation of connectivity between education and research systems; d) capacity building of agroforestry staff; e) policy advocacy on agroforestry; e) information and communications; and, f) resource generation and mobilization. 
SEANAFE's establishment paved the way to the creation of the Philippine Agroforestry Education and Research Network (PAFERN) as an informal coalition of agriculture and forestry academic institutions in 1998 up to its formal establishment in 2003. Since then, PAFERN has been implementing a number of national and institutional activities funded by Sida through SEANAFE. PAFERN works towards: a) building institutional capacities for improved delivery of agroforestry education; b) strengthening institutional capacities for collaborative agroforestry research and extension; c) improving learning facilities in agroforestry; d) promoting multisectoral partnerships in agroforestry development; e) creating venues for information exchange among agroforestry stakeholders; f) intensifying institutional linkages; and g) mobilizing and generating resources for sustained operation.

In their report on the Impact of SEANAFE to its member-institutions, Rudebjer, et al (2007) mentioned that the Network's activities have influenced the status and changes that have taken place in agroforestry education in the region. Significant improvements were observed on: a) the capacities of the agroforestry teaching staff in handling agroforestry courses; b) the quality and quantity of teaching materials and facilities; and c) the number of research and extension projects.

After eight years of regional networking, SEANAFE decided to undertake another survey in 20072008 to update the agroforestry education profiles of its member countries. Survey questionnaires were emailed to designated contact persons of country network institutions who served as direct respondents. The survey results were expected to guide SEANAFE in identifying projects and activities to undertake in the future to continue accomplishing its vision-mission of improving livelihoods and ensuring sustainable rural development in the region through improved agroforestry education.

This report summarizes the data collected from $22(65 \%)$ out of 34 member institutions of PAFERN which completed the SEANAFE survey from December 2007 to September 2008. Project experiences and other relevant documents of SEANAFE and PAFERN also provided additional information to this report. 


\section{Development of Agroforestry Education in the Philippines}

Agroforestry is an age-old practice in the Philippines. Literatures say that the famous Banawe Rice Terraces built by the Ifugao ancestors many decades ago is a classic example of an agroforestry system in the country.

The widespread practice of agroforestry paved the way for its recognition as a science in the 70s. Agroforestry education began in the Philippines as early as in 1976 when the Don Mariano Marcos Memorial State University (DMMMSU) offered a degree program leading to BSAF. Since then, 33 other academic institutions also began implementing different types of agroforestry education programs.

The 34 academic institutions engaged in agroforestry education programs are widely spread in the Philippines (Please see Attachment A for the complete list). There are $20(60 \%)$ institutions in Luzon, seven (17\%) and eight (23\%) in Mindanao (Figure 1). These institutions are classified as state university (19), state college (14), private university (1), and one institution supervised by the Technical Skills and Development Authority (TESDA) (Figure 2).

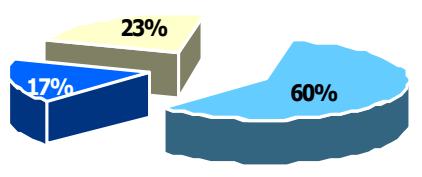

Luzon

Mindanao

Visayas

Figure 1. Geographical distribution of PAFERN institutions engaged in agroforestry education programs.

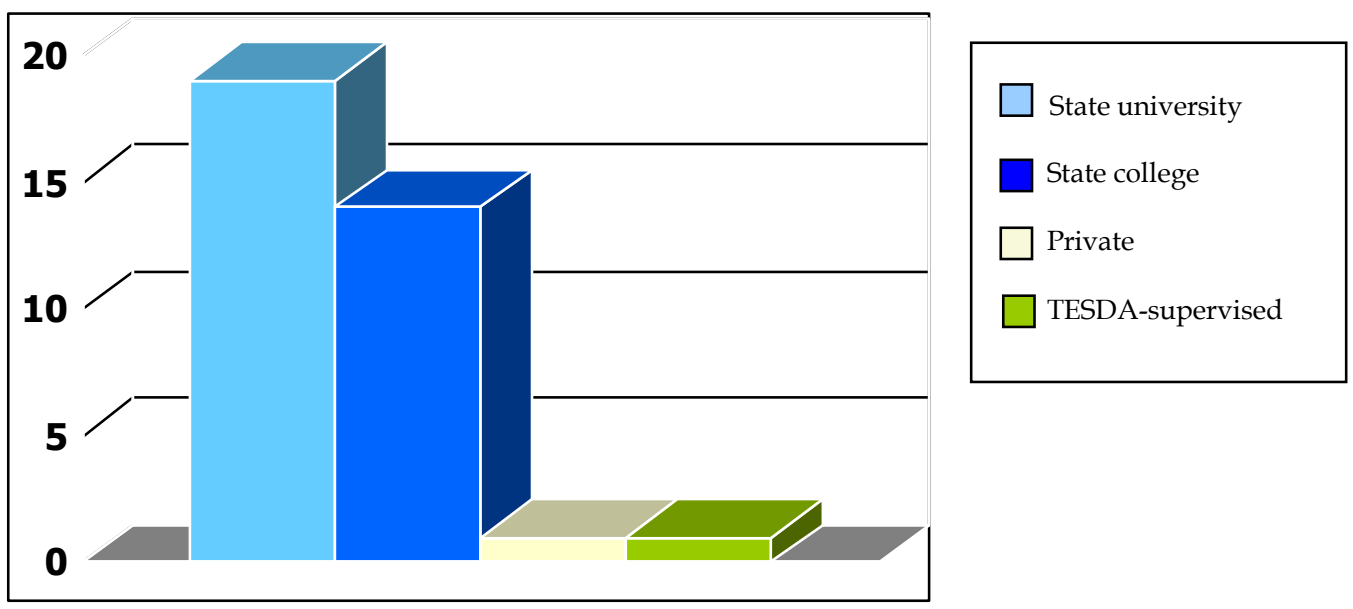

Figure 2. Classification of academic institutions engaged in agroforestry education programs. 
Table 1 indicates that 32 percent of the surveyed institutions were offering agroforestry education programs to address societal and stakeholders' needs (e.g. the prospective employers and local communities). It was noted that some of them are situated in municipalities or provinces with vast upland areas. Thus, these institutions have also perceived the need to promote agroforestry as an appropriate land use management system that would address environmental concerns within their respective areas. Two institutions, meanwhile, offered the BSAF program in response to the Commission on Higher Education (CHED) Memorandum Order No. 9, Series of 2006, which calls for the adoption of the new Policy, Standards and Guidelines (PSG) for BSAF. This PSG has been absent in the Philippines for the last two decades. Surprisingly, also 32 percent of the institutions did not provide reasons for the offering of their agroforestry curricular programs. This may be because the individual respondents may not have been involved in developing the agroforestry curriculum of their respective institutions.

Table 1. Reasons for the implementation of agroforestry curricular programs in the Philippines.

\begin{tabular}{|l|c|c|}
\hline \multicolumn{1}{|c|}{ REASONS } & FREQUENCY & PERCENTAGE \\
\hline $\begin{array}{l}\text { To respond to the needs of the community (e.g. high school students, } \\
\text { potential employers) and the recent environmental issues (e.g. climate } \\
\text { change, environmental degradation) }\end{array}$ & 32 \\
\hline $\begin{array}{l}\text { To help address the degradation of upland areas within the municipality } \\
\text { or province where the agroforestry school is situated }\end{array}$ & 4 \\
\hline In response to the CHED Memo No. 9, Series of 2006 & 2 & 1 \\
\hline $\begin{array}{l}\text { Agroforestry is perceived as the most appropriate approach in land } \\
\text { resource use }\end{array}$ & $\mathbf{2}$ \\
\hline To enrich the curricular program of the school & $\mathbf{1}$ \\
\hline No answer & $\mathbf{4}$ \\
\hline Total & $\mathbf{7}$ \\
\hline
\end{tabular}




\section{Milestones in the Development of Agroforestry Education Programs in the Philippines}

The Philippines has seen a gradual but study development of agroforestry education since 1976 up to the present. The following chronicles the major events that have shaped agroforestry education as it is now in the country.

- 1976 - first offering of the BSAF program by DMMMSU through the Institutional Assistance Program of UPLB and the Technical Panel for Agricultural Education

- 1981 - issuance of the Ministry of Education, Culture and Sports (MECS) Order No. 3, stipulating the minimum standards and requirements for the implementation of the BSA-AF and BSF-AF

- 1983 - first offering of the BSA-AF by the Benguet State University and the Aklan State College of Agriculture (now Aklan State University)

- 1987 - first offering of the BSF-AF by the Bicol University College of Agriculture and Forestry

- 1995 - observed exponential growth of educational institutions engaged in agroforestry programs as indicated by the results of the Philippine Agroforestry Education Needs Assessment (PHILAFENA) conducted by the UPLB-IAF among 18 agroforestry institutions)

- 1998 - Status and Needs Assessment of Agroforestry Education and Training in the Philippines conducted by UPLB-IAF revealed the proliferation of agroforestry schools totaling to 31 institutions. It was also this year when the First National Workshop on Agroforestry Education was organized by the Institute. Through this workshop, PAFERN was established as an informal coalition

- 1999 - Formal establishment of SEANAFE which influenced the formation of other country networks in Indonesia, Laos, Thailand, and Vietnam

- 2000 - Study on the Demand and Placement of Agroforestry Graduates in the Philippines conducted by the UPLB-IAF revealed the market demand for BS Agroforestry graduates

- 2000 - National Workshop on Participatory Agroforestry Curriculum Development was organized by SEANAFE and the UPLB-IAF which served as a venue to draft the curricular framework for the BSAF program

- 2001 - Formal organization of PAFERN leading to the drafting of a resolution addressed to the CHED to create a Taskforce on Agroforestry Education

- 2003 - Official creation of the Taskforce on Agroforestry Education by the CHED to primarily formulate the minimum standards for the BSAF program 
- 2006 - Approval of the new PSG for BSAF from the CHED Memorandum Order No. 9, Series of 2006. This PSG specifies the minimum standards and requirements for the offering of the BSAF program. These standards were absent for almost three decades. The Memorandum also calls for the adoption of the BSAF and phasing out of other variants of agroforestry curricula such as BSA-AF, BSF-AF, Bachelor in Agroforestry Technology (BAFT), and BS Agroforestry Entrepreneurship (BSAFE)

- 2007 - effectivity of implementation and adoption of the new PSG for BSAF 


\section{Variants of Agroforestry Curricular Programs in the Philippines}

As the number of agroforestry schools increased, the various types of agroforestry curricular programs also consequently proliferated in the Philippines. As of 2007, there were already six variants of agroforestry programs at the baccalaureate/undergraduate level. These included the BSAAF, BSF-AF, BAFT, BAFE, BSAFE and BSAF (Table 2). However, with the approved new PSG for BSAF, all agriculture and forestry institutions are expected to phase out other variants of agroforestry programs soon.

Meanwhile, two programs are available at the technician's level in six PAFERN institutions. These include a two-year terminal program leading to Certificate/Diploma in Agroforestry, and the ladderized Diploma in Agroforestry Technology (DAFT) leading to BAFT. Both programs train students on agroforestry development skills and entrepreneurship.

Of the 22 academic institutions surveyed, nine (9) were offering BSAF; one (1) BSA-AF; three (3) BSF-AF; six (6) either terminal or ladderized Diploma in Agroforestry; two (2) BAFT, and one (1) Master of Science in Agroforestry (MSAF) Program (Table 2). Meanwhile, aside from the nine institutions already offering BSAF program, another three of them were already set to offer the same program in 2009. As of yet, agroforestry is offered either as a core course in other related programs as BSF, BSA or BS Agricultural Engineering, or as thesis topic under the existing BSF curriculum.

Table 2. Variants of agroforestry curricular programs in the Philippines.

\begin{tabular}{|c|c|c|c|}
\hline \multirow{2}{*}{ Types of agroforestry curricula } & \multicolumn{3}{|c|}{$\begin{array}{l}\text { Number of academic institutions per island group in the } \\
\text { Philippines }(n=22)^{*}\end{array}$} \\
\hline & Luzon & Visayas & Mindanao \\
\hline BSAF & 7 & 1 & 1 \\
\hline BSA-AF & 0 & 1 & 0 \\
\hline BSF-AF & 3 & 0 & 1 \\
\hline BAFT & 1 & 0 & 1 \\
\hline BSAFE & 0 & 0 & 1 \\
\hline DAFT & 1 & 0 & 1 \\
\hline DAF & 2 & 1 & 1 \\
\hline MSAF & 1 & 0 & 0 \\
\hline
\end{tabular}

${ }^{*}$ multiple response

As shown in Table 3, the survey also revealed that six agroforestry courses were being offered in at least one institution as core courses in other programs, namely: (1) Fundamentals of Agroforestry under both BSA and BSF programs; (2) Soil and Water Conservation and Management and Agroforestry Farming System under the BSA program; (3) Upland Farming Systems, (4)

Agroforestry Systems Design and Development, (5) Agroforestry Project Planning and Management, and (6) Agroforestry Production and Post Production System under the BSF program. 
Table 3. Other schemes by which the teaching of agroforestry is integrated in other degree programs and courses in the Philippines.

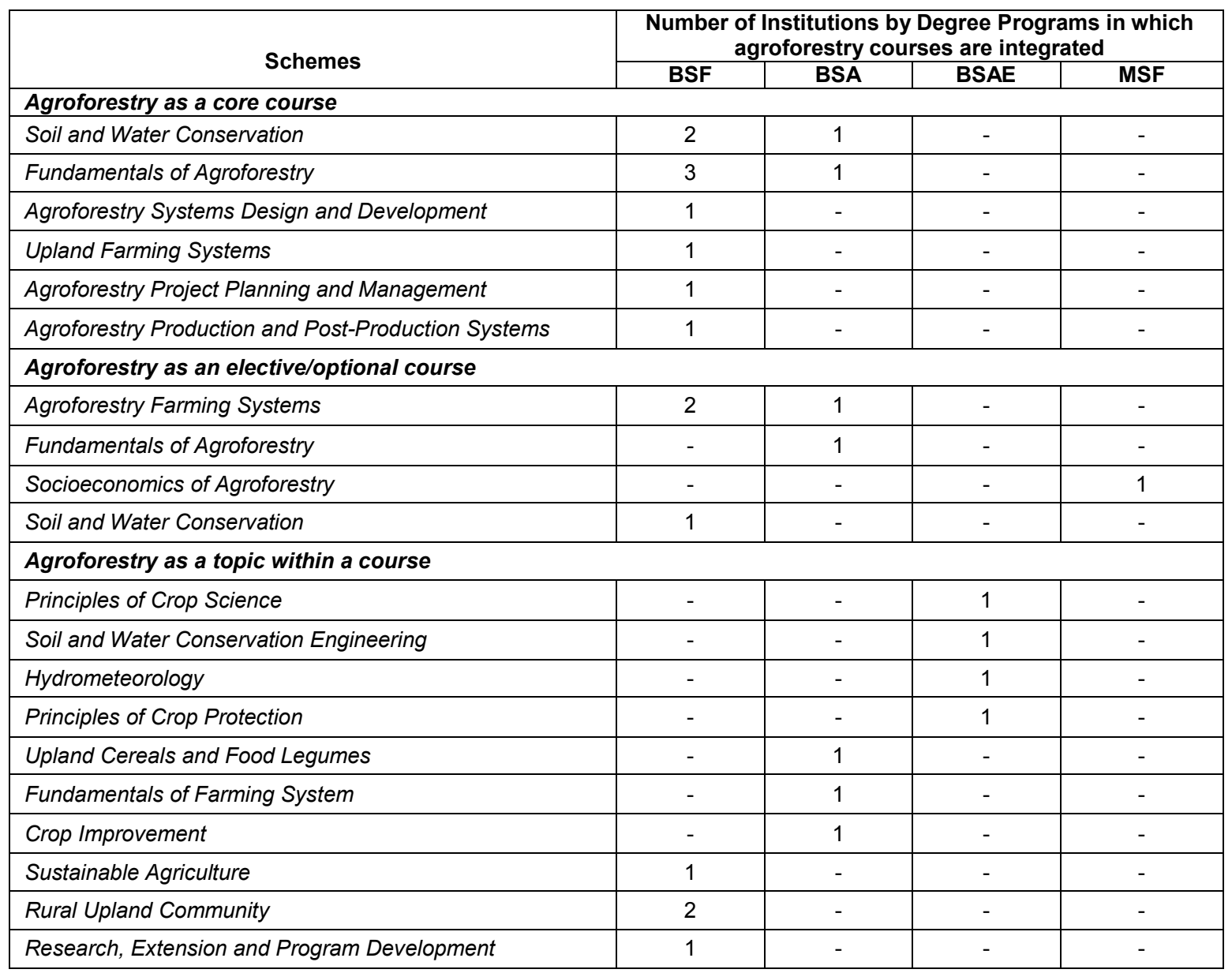

Likewise, agroforestry was included as a topic in 10 undergraduate courses such as (1) Water Conservation Engineering, (2) Principles of Crop Protection, (3) Upland Cereals and Food Legumes, (4) Crop Improvement, (5) Hydrometeorology, (6) Pasture and Fodder Crops, (7) Fundamentals of Farming Systems, (8) Rural Upland Community, (9) Sustainable Agriculture, and (10) Research, Extension, and Program Development. 


\section{Agroforestry curriculum development process in the Philippines}

In the Philippines, the responsibility of curriculum development has largely been given to faculties which intend to offer a particular course or program particularly among autonomous SCUs. Approval by higher authority becomes a matter of formality to ensure that the concerned institution has fully complied with the basic requirements.

Nevertheless, curriculum development in agroforestry in the Philippines is constrained by several factors. Foremost is the turf issue between the faculties of agriculture and forestry. In the absence of a separate faculty or institute on agroforestry, the turf issue relates to who has the right and responsibility to develop and offer an agroforestry course and/or program. This issue has affected the adoption of the CHED-prescribed BSAF curriculum in most of PAFERN institutions. Interestingly, five of the nine institutions surveyed offering BSAF programs have already established separate units to manage the implementation (Table 4).

Table 4. Number of institutions offering agroforestry education programs by base departments/faculties.

\begin{tabular}{|l|c|c|c|}
\hline \multirow{2}{*}{\multicolumn{1}{c|}{ Type of agroforestry education programs }} & \multicolumn{3}{c|}{$\begin{array}{c}\text { Number of institutions offering agroforestry education } \\
\text { programs by base departments/ faculties }\end{array}$} \\
\cline { 2 - 4 } & Agriculture & Forestry & Agroforestry $^{*}$ \\
\hline BSA-AF & 1 & & - \\
\hline BSF-AF & - & 4 & 5 \\
\hline BSAF & 2 & 2 & - \\
\hline BAFT & 1 & 1 & 1 \\
\hline BSAFE & - & - & 1 \\
\hline DAFT & 1 & 1 & - \\
\hline Diploma/Certificate in AF & - & 4 & 1 \\
\hline MSAF & - & - & \\
\hline
\end{tabular}

${ }^{*}$ multiple responses

Another constraint mentioned by the survey respondents was that few faculty members participate in the course and/or program curricular reviews. This may be brought about by the fact the process is tedious and usually consumes much staff time considering the multi functions faculty members have to perform daily in their respective institutions. The lack of adequate funds was also considered by some institutions as a constraint in convening stakeholders to participate in the curriculum development and review to ensure relevant outputs.

Most of the respondents did not provide answer on when their institutions last conducted a curricular review of their existing agroforestry courses and/or programs. Perhaps, there had been no curricular reviews conducted yet or they were not fully aware of it. In her study entitled "Effectiveness of PAFERN in Strengthening the Quality of Agroforestry Education in the Philippines," Landicho (2005) reported that agroforestry curricular programs were being revised every five years by most of the network's member-institutions. Those institutions that conducted curricular reviews in 20062007 were responding to the CHED Memorandum Order No.5, Series of 2006 requiring all state colleges and universities to adopt the new PSG for BSAF (Table 5). 
Table 5. Number of institutions that conducted agroforestry curricular reviews per type of program from 1995 to 2007 .

\begin{tabular}{|c|c|c|}
\hline Period of agroforestry curricular review & Diploma Program & BS Program \\
\hline $1995-2000$ & 2 & 1 \\
\hline $2001-2005$ & 1 & 6 \\
\hline $2006-2007$ & 4 & 14 \\
\hline No answer & 15 & 1 \\
\hline
\end{tabular}

In terms of the strategies adopted by the surveyed institutions in conducting agroforestry curriculum development and review, most of them have organized consultative workshops to get the participation of various stakeholders (e.g. private and government sectors, local communities, non-government organizations) (Table 6). Others have conducted needs assessment studies/surveys. These strategies were done to identify the demand and competency requirements of the prospective employers of agroforestry graduates.

Table 6. Strategies in agroforestry curriculum development and review.

\begin{tabular}{|c|c|}
\hline Strategies & Frequency $(n=22)^{*}$ \\
\hline Organize consultative workshops involving different stakeholders & 9 \\
\hline Conduct needs assessment surveys/studies & 3 \\
\hline Series of reviews by the different review bodies of the school & 3 \\
\hline Followed the CHED Memorandum Order No. 9, Series of 2006 & 3 \\
\hline Pattern the curriculum from other schools & 1 \\
\hline No answer & 7 \\
\hline
\end{tabular}

Some schools that were planning to offer degree programs in agroforestry feared that their graduates might become unemployed considering the recent unemployment issues from the fields of agriculture, forestry, agroforestry and other allied programs. In addition, the declining enrolment encouraged some academic institutions to just offer agroforestry as a core course in their existing programs in agriculture or forestry, rather than instituting a separate curricular program for agroforestry.

Incidentally in 2008, four of the surveyed institutions availed themselves of small grants from SEANAFE to mainstream the outputs of its "Markets for Agroforestry Tree Products (MAFTP)" project, i.e., the curricular framework themes and case study materials, in their existing agroforestry and related courses under the BSAF program. In doing so, these institutions conducted curricular review workshops with stakeholders and course syllabus development. The MAFTP themes were mostly integrated as additional topics in courses such as Entrepreneurship in Agroforestry, Processing and Utilization of Agroforestry Products, Agroenterprise Development and Management, and Agroforestry Governance, Policies and Programs (Please refer to the link on a SEANAFE poster on "Integrating the Teaching of markets for Agroforestry Tree Products in Agroforestry Education in Southeast Asia" at http://www.worldagroforestry.org/sea/apps/publications/searchpub.asp?publishid=2214) 


\section{Enrolment and students' performance in agroforestry education programs}

In general, the survey indicated a decreasing enrolment trend in BSAF curricular program in the Philippines among the surveyed institutions (Table 7). This finding validates SEANAFE's 2006 impact study report and the study by Carandang, et al (2008) on the Demand and Supply of Forestry Graduates in the Philippines as regards the declining interest among students to study agriculture and forestry sciences. Carandang, et al noted that enrolment in 17 forestry schools they surveyed was at its peak in SY 1999-2000 with 4, 105 students and dropped to 2,701 students in SY 2004-2005. The SEANAFE impact study also observed this trend in Indonesia and Thailand.

Table 7. Observed enrolment trend in agroforestry education programs.

\begin{tabular}{|l|c|c|c|}
\hline \multirow{2}{*}{ Agroforestry education programs } & \multicolumn{2}{|c|}{ Number of institutions by enrolment trend for the last 5 years } \\
\cline { 2 - 4 } & Increasing & Stable & Decreasing \\
\hline Diploma & 4 & - & - \\
\hline Bachelor/Baccalaureate & 2 & 3 & 17 \\
\hline MS/Graduate program & - & - & 1 \\
\hline Total & $\mathbf{6}$ & $\mathbf{3}$ & $\mathbf{1 8}$ \\
\hline
\end{tabular}

The declining enrolment in the agroforestry education programs can be attributed to the perceived limited employment opportunities for the graduates. This perception validates the results of the Study on the Demand and Placement of Agroforestry Graduates in the Philippines conducted by the UPLBIAF in 2001 indicating unemployment or underemployment of most agroforestry graduates. This explains why many students are now inclined to take non-agriculture or non-forestry programs such as information technology and nursing. Some respondents also argued that the proliferation of schools offering agroforestry education program promotes competition for prospective students among them.

This study also observed that the students enrolled in the agroforestry curricular programs could not complete their programs as indicated by five $(23 \%)$ of the surveyed institutions (Figure 3). Students could not sustain their studies and drop out from the program because of financial constraints. Other students, however, have shifted to other non-agroforestry/forestry programs such as information technology and nursing with the expectations of having a better employment prospect after graduation. 


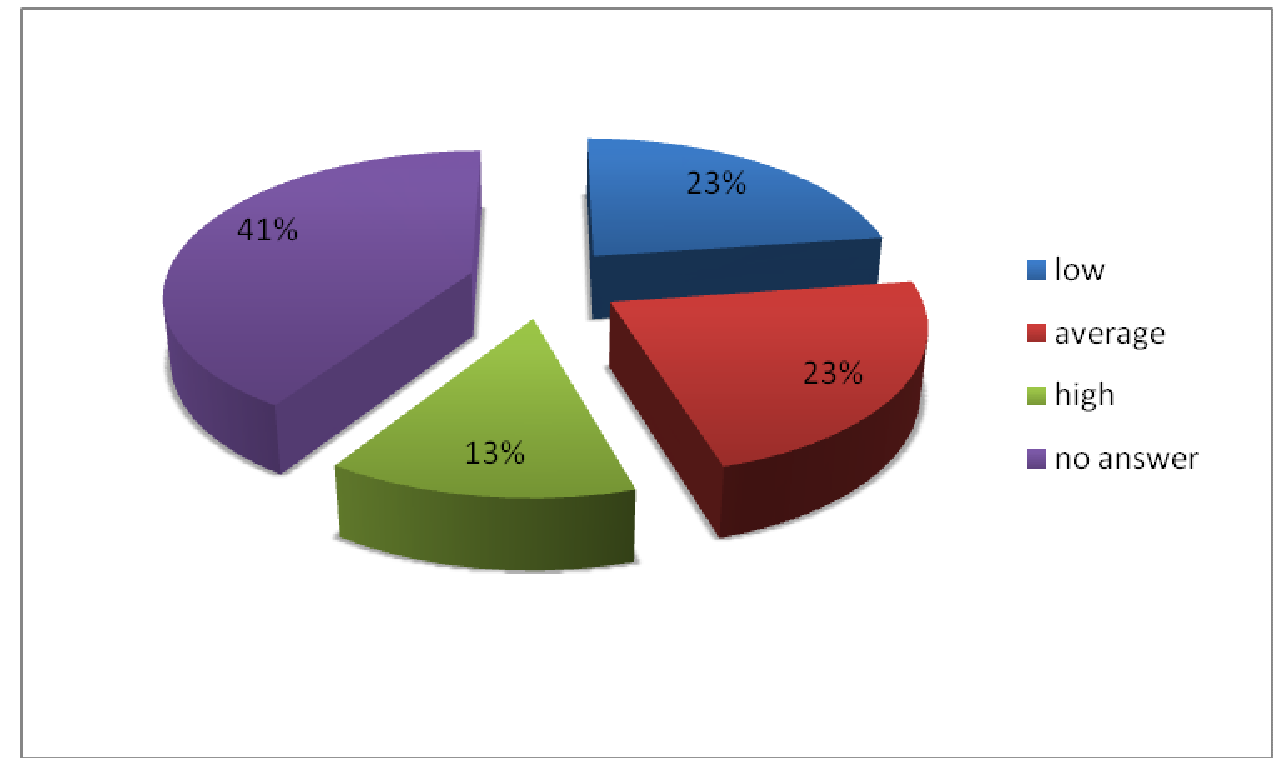

Figure 3. Rate of completion of baccalaureate/undergraduate degree among BSAF students. 


\section{Teaching staff in agroforestry}

A total of 226 faculty members comprised the teaching staff involved in agroforestry education in all the 22 surveyed institutions. Of this number, 137 faculty members comprised the full-time agroforestry teaching staff. Table 8 shows that most (43.07\%) of these full-time agroforestry teaching staff were MS degree holders while $33.58 \%$ of them were $\mathrm{PhD}$ degree holders. Most of them had specialization in forestry.

Majority (95\%) of the surveyed institutions indicated that the qualifications of their agroforestry teaching staff have improved for the past five years because of their attendance to trainings, seminars, and conferences, including involvements in book writing. These exposures helped the faculty members enrich their field experiences and teaching capacities, as well.

Table 8. Profile of teaching staff involved in the agroforestry education programs.

\begin{tabular}{|l|c|c|}
\hline Fields of specialization of teaching staff (full-time + affiliates/part time) & Number & Percent \\
\hline Agroforestry & 20 & 8.85 \\
\hline Agriculture & 59 & 26.11 \\
\hline Forestry & 82 & 36.28 \\
\hline Rural development & 17 & 7.52 \\
\hline Sociology & 21 & 9.29 \\
\hline Others (e.g. biology, education, ) & 27 & 11.95 \\
\hline Total & $\mathbf{2 2 6}$ & $\mathbf{1 0 0 . 0 0}$ \\
\hline Educational qualifications of full-time teaching staff & 23.36 \\
\hline BS & 32 & 43.07 \\
\hline MS & 59 & 33.58 \\
\hline PhD & 46 & $\mathbf{1 0 0 . 0 0}$ \\
\hline Total & $\mathbf{1 3 7}$ & 95.45 \\
\hline Status of qualifications of teaching staff & & 0.00 \\
\hline Improving & 21 & 4.55 \\
\hline Stable & 0 & $\mathbf{1 0 0 . 0 0}$ \\
\hline Not improving & 1 & $\mathbf{1 0 0 . 0 0}$ \\
\hline Total & $\mathbf{2 2}$ & \\
\hline $\begin{array}{l}\text { Attendance of teaching staff to staff development programs (e.g. } \\
\text { seminars, conferences, workshops) }\end{array}$ & & 5.10 \\
\hline Frequent attendance & $\mathbf{2 2}$ & \\
\hline Seldom attendance & 11 & 40.90 \\
\hline No staff development program & 9 & 0.00 \\
\hline No answer & 0 & \\
\hline Total & 2 & \\
\hline
\end{tabular}




\section{Agroforestry teaching materials and facilities}

Figure 4a indicates that except for the field laboratories, most of the agroforestry teaching materials and facilities were apparently lacking in most of the surveyed institutions. This was usually attributed to limited school budget. On a positive note, however, these teaching materials and facilities, while mostly inadequate, were found to be always available for use by the students and faculty members (figure $4 b$ ).

The surveyed institutions acknowledged SEANAFE, PAFERN, ICRAF, Department of Environment and Natural Resources, UPLB-IAF, and other schools as sources of their teaching materials such as journals, books, teaching manuals and lecture notes.

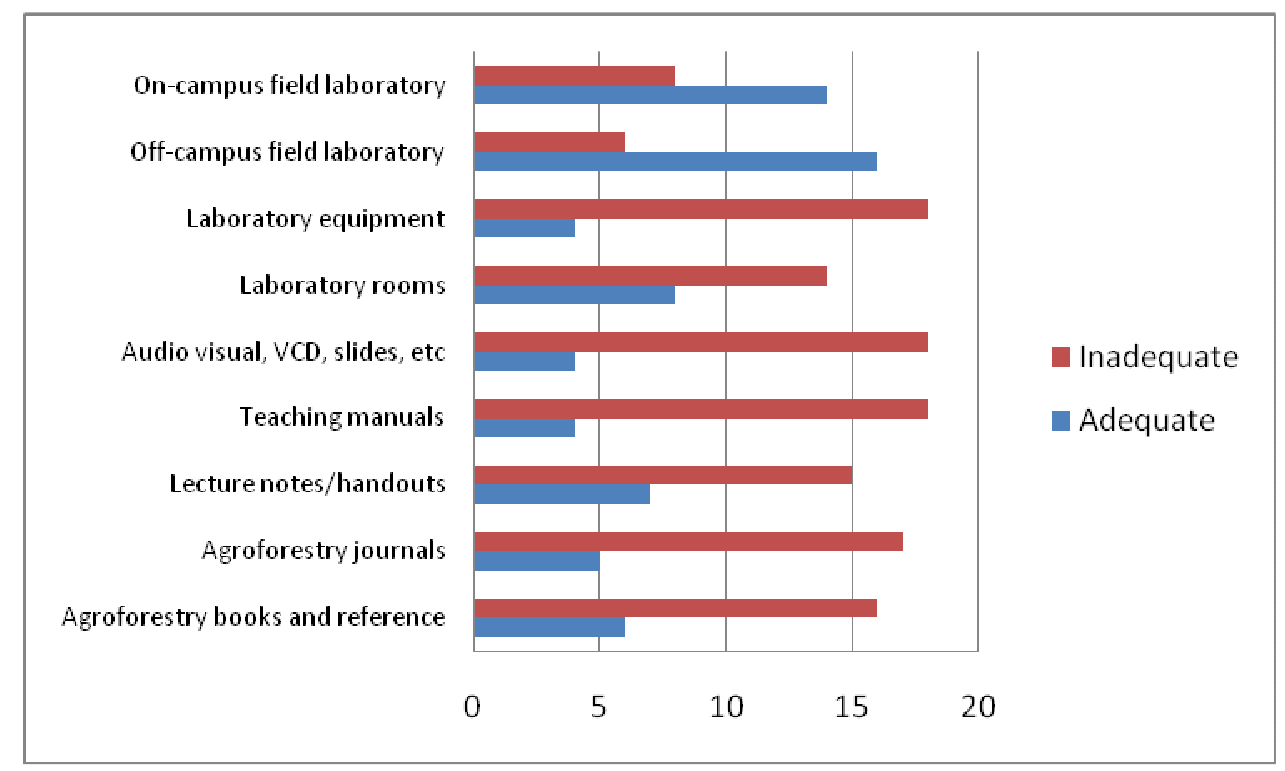

Figure 4a. Adequacy of agroforestry teaching materials and facilities in the surveyed institutions 


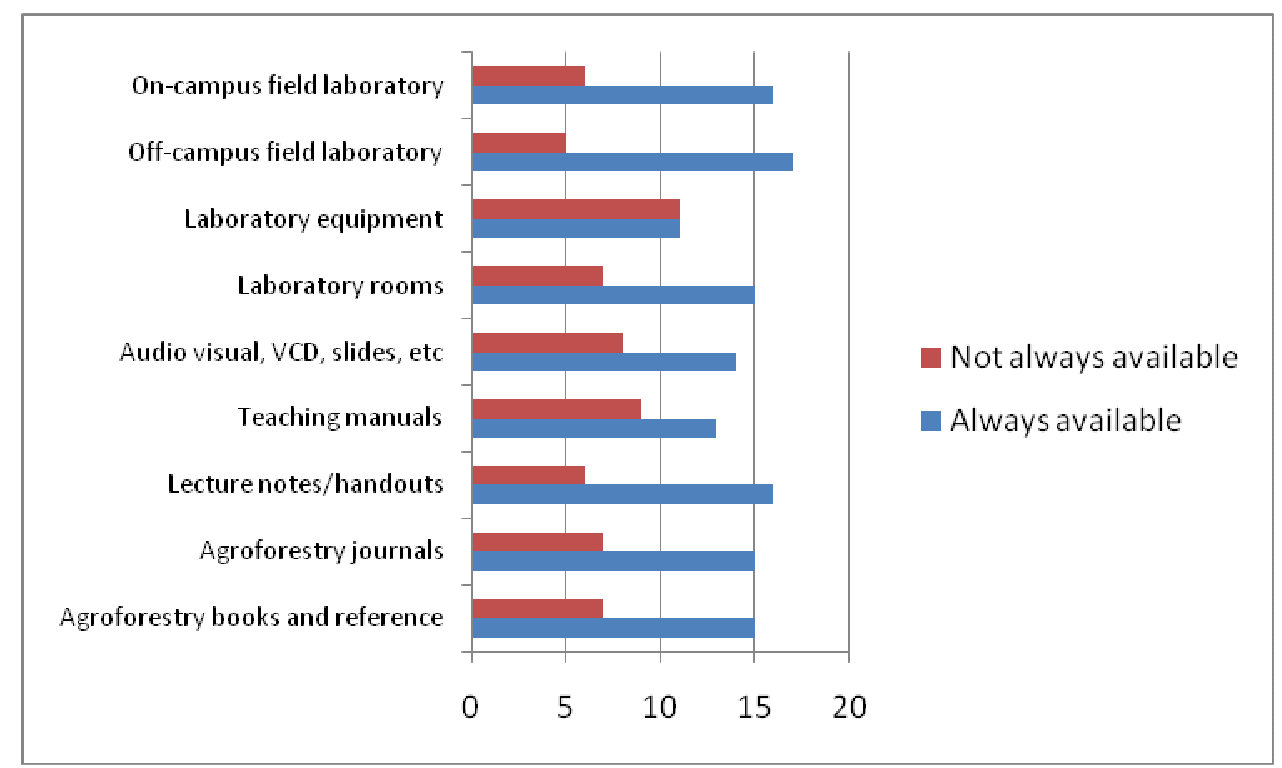

Figure $\mathbf{4 b}$. Availability of agroforestry teaching materials and facilities in the surveyed institutions. 


\section{Agroforestry extension programs and services}

As mandated by law, state colleges and universities in the Philippines perform four-fold functions, namely: instruction, research, extension, and production. At least 14 (64\%) of the surveyed institutions were engaged in various forms of extension programs and services (Figure 5). Majority $(95 \%)$ were providing institutional extension projects and maintaining on-campus agroforestry demonstration plots as learning laboratories fro students, faculties, farmers, and other clients.

Most of the narrative comments given by the surveyed institutions revealed they have limited financial and manpower resources to provide extension services. Because of the heavy teaching loads, some faculty members could no longer engage themselves in implementing agroforestry extension programs.

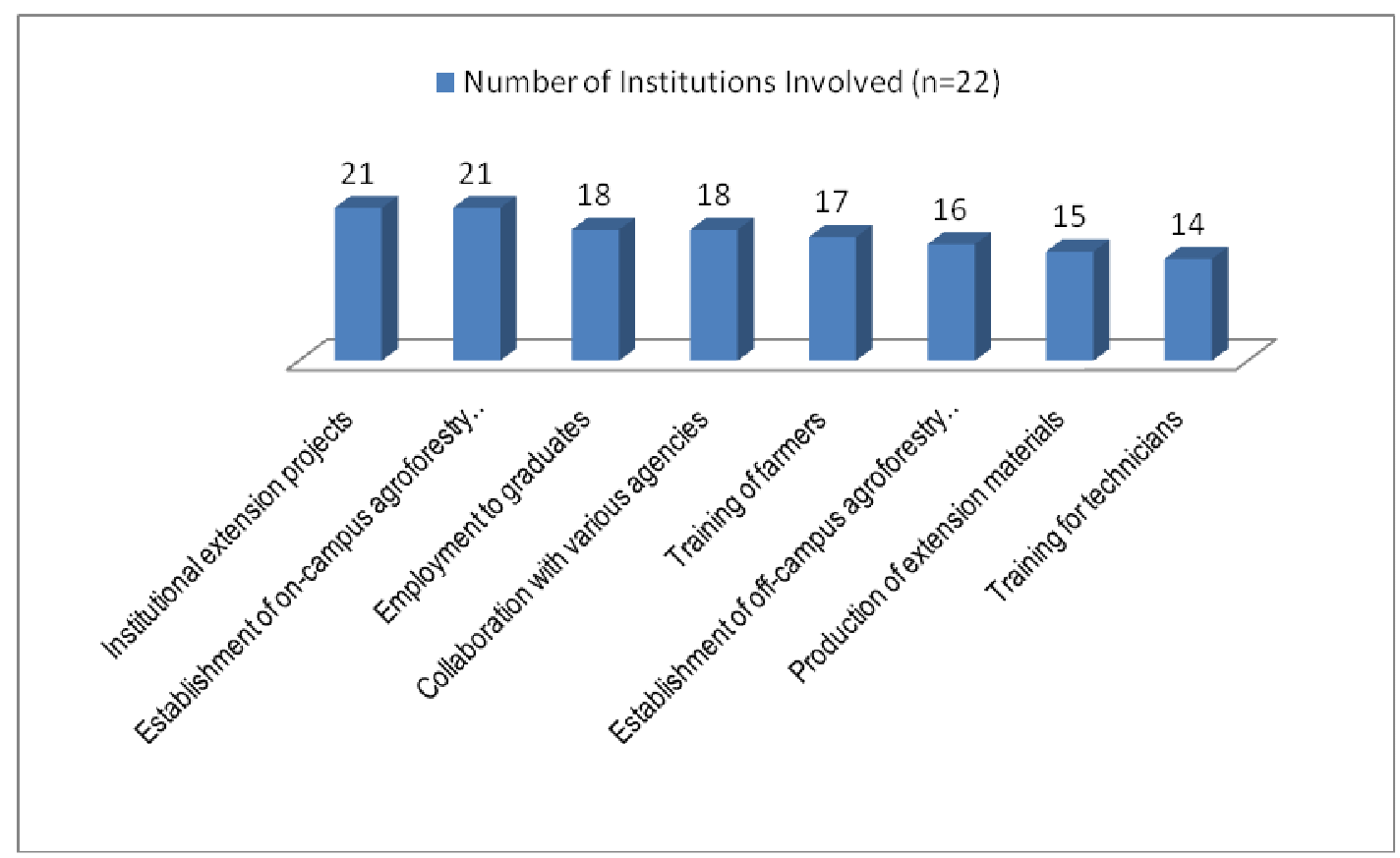

Figure 5. Types of agroforestry extension programs of surveyed institutions. 


\section{Agroforestry research programs}

Interestingly, seven (32\%) of the surveyed institutions indicated an increasing trend in the number of (a) their faculty members involved in agroforestry research, (b) active agroforestry research projects, and (c) research papers presented in agroforestry related conferences (Table 9). This number may have been more if their major constraints in research funds and too much teaching loads of their faculty members could be properly addressed. On the other hand, it appears that publishing agroforestry research articles in journals and encouraging students to conduct their thesis on agroforestry were not being given much attention by these institutions. Most narrative comments given by the surveyed institutions attributed this to work load and the personal interest of the faculty members and students. However, respondents who gave no answers may not really have a full knowledge on agroforestry research involvements of faculty members and students.

Table 9. Status of agroforestry research in the respondent-institutions.

\begin{tabular}{|c|c|c|c|c|}
\hline \multirow{2}{*}{ Indicators of Involvement in Agroforestry research } & \multicolumn{4}{|c|}{ Number of institutions by status trend $(n=22)$} \\
\hline & Increasing & Stable & Decreasing & No Answer \\
\hline $\begin{array}{l}\text { Number of faculty members involved in agroforestry } \\
\text { research }\end{array}$ & 7 & 9 & 2 & 4 \\
\hline Number of active agroforestry research projects & 7 & 5 & 4 & 6 \\
\hline Number of thesis in agroforestry & 5 & 3 & 5 & 9 \\
\hline Number of articles published in a journal & 3 & 5 & 2 & 11 \\
\hline Papers presented in agroforestry conferences & 7 & 3 & 4 & 8 \\
\hline
\end{tabular}




\section{Conclusions}

As discussed earlier, previous assessment studies conducted in 1995 and 1998 revealed a gloomy scenario of agroforestry education in the Philippines such as lack of guiding principles and minimum standards in agroforestry; lack of basic references and teaching materials in agroforestry; limited staff development opportunities for agroforestry teaching staff; and weak agroforestry research programs.

This current assessment report on Philippine agroforestry education indicated a considerable progress in the last 10 years. The PSG for BSAF that has been absent for 20 years has become available for use by the academic institutions. The teaching staff capacity has improved brought about by the improving qualifications in terms of levels of education, and the participation in various staff development programs. The field facilities have likewise improved both on-campus and off-campus. While teaching materials in most of the 22 respondent-institutions are inadequate, these are always available for use by the students and faculty members.

However, agroforestry research and extension programs need further attention. There seems to be very limited opportunities to conduct research and extension because of resource constraints. On the other hand, the biggest challenge being faced by PAFERN institutions is the declining student enrolment in agriculture, forestry and agroforestry programs. Drastic changes are called for to address these challenges to help promote the growing interest on agroforestry in addressing global economic and environmental concerns. 


\section{Recommendations}

1. Academic institutions and agroforestry networks, e.g. PAFERN and National Agroforesters' Association of the Philippines (NAAP), should establish more innovative recruitment, curricular review, and job placement programs to make agroforestry education more attractive to students and prospective employers. Offering of more scholarship programs and sustained technical assistance and counseling could be among the many strategies of academic institutions to attract more students, and facilitate the completion of their degree programs. On the other hand, purposive on-the-job trainings of students coupled with dialogues and other institutional arrangements with prospective employers could enhance their employability after graduation. Academic institutions must take advantage of the need for agroforestry competencies of development organizations, and local and national government agencies as revealed by the UPLB-IAF study on "Assessing the Need for Agroforestry Competencies in the Philippines" in 2009. There must be a continuous monitoring of such need toward revising course and program curricula accordingly to match the required/preferred agroforestry competencies of employers.

2. PAFERN and NAAP as recognized agroforestry networks in the Philippines should lobby with the local government units (LGUs) in creating core positions for agroforestry graduates. Since LGUs have expressed their needs for agroforestry competencies in executing their functions, they are thus considered as among major employers of agroforestry graduates. Their authority to create local positions within their jurisdiction, particularly for agroforestry, should be tapped to the fullest to assure employment of agroforestry graduates.

3. The academic institutions engaged in agroforestry education programs should proactively implement agroforestry research and extension programs. Outputs from any research and extension activities have proven to enhance curricular offerings of learning institutions once fully integrated. While it is understandable that research and extension funds are limited due to declining government subsidy, SCUs should nevertheless try to diversity their funding sources to carry out these mandates effectively. Teaching and research staff should be encouraged and given more time to develop relevant and responsive research proposals for funding. On the other hand, PAFERN should also promote inter-institutional research and extension collaborations among its members for a more effective and efficient sharing of resources. Such collaborations may not have to involve big amounts of money and could be in the forms of exchanges in services, and use of facilities and equipment.

4. Corollary to No. 3, faculty members should aggressively promote agroforestry as thesis topic of students. Students are very potent resource of any learning institutions. They could be encouraged to do preliminary studies of research projects of faculty members and thus could save on manpower expenses. But more importantly, this scheme would ensure proper mentoring of students considering that both the faculty and the students are working on same research topic. In the process, this strengthens faculty-student relationship in producing research outputs for the institution. The impact could mean more appreciation and interest of agroforestry among students as a program of study.

5. The agroforestry teaching staff and researchers should actively search for and participate in capacity building opportunities to improve teaching methods, approaches, and contents. Capacity building must be a continuing activity among learning institutions. While it is true that attendance to training courses, seminars and workshops may be costly, teaching and research staff members must be encouraged to submit papers for oral and poster presentations to scientific conventions, conferences, and meetings. These activities could provide them 
opportunities to acquire new knowledge, including materials, and also establish new and strengthen existing linkages with like-minded individuals and organizations. There are also other ways to build capacities internally within an institution such as brainstorming sessions in developing new projects, peer-review sessions of research results, weekly or monthly seminars to present research outputs, etc.

6. PAFERN and NAAP should come up with a database of essential agroforestry teaching materials available in the country for effective and efficient sharing among the learning institutions and ensuring the quality of teaching agroforestry to students. With the CHED Memorandum Order No.5, Series of 2006 requiring all state colleges and universities to adopt the new PSG for BSAF, it now becomes necessary to determine the stock of agroforestry teaching materials existing among the different institutions offering the program. 


\section{References}

Carandang, M.G., L.D. Landicho, R.T. Andrada, P.L. Malabrigo, A.Angeles, A.T. Oliva, and F.M. Eslava. 2008. Demystifying the State of Forestry Education in the Philippines. Ecosystems and Development Journal 1(1): 27-35.

Fernandez J. 2009. Integrating the Teaching of "Markets for Agroforestry Tree Products" in university Curriculum in Southeast Asia: The SEANAFE Experience. A Poster. Bogor, Indonesia. World Agroforestry Centre - ICRAF, SEA Regional Office.

Landicho, L.D. 2005. Effectiveness of the Philippine Agroforestry Education and Research Network (PAFERN) in Strengthening the Quality of Agroforestry Education in the Philippines. MS Thesis. College of Public Affairs, University of the Philippines Los Banos, College, Laguna. Unpublished.

Policy, Standards, and Guidelines for BS Agroforestry Program. 2006. Philippine Commission on Higher Education Memorandum Order No.9. Pasig City, Philippines

Rudebjer, P.G. and R.A. del Castillo. 1999. How Agroforestry is Taught in Southeast Asia- A Status and Needs Assessment in Indonesia, Lao PDR, the Philippines, Thailand and Vietnam. Training and Evaluation Report No. 48. Bogor: ICRAF

Rudebjer, P.G., L.D. Landicho, D. Pipatwattanakul, I.Z. Siregar, D.D. Boi. 2007. Impact of the Southeast Asian Network for Agroforestry Education (SEANAFE) on Agroforestry Education Capacity. A Working Paper no. 73. SEANAFE -ICRAF Regional Office, Bogor, Indonesia 
Appendix 1. Academic institutions engaged in agroforestry education programs in the Philippines.

\begin{tabular}{|c|c|c|c|}
\hline Academic institution & Classification & $\begin{array}{c}\text { Agroforestry curricula } \\
\text { being offered }\end{array}$ & Remarks \\
\hline $\begin{array}{l}\text { 1. Abra State Institute of } \\
\text { Science and Technology } \\
\text { (ASIST) }\end{array}$ & State college & $\begin{array}{l}\text { Diploma in Agroforestry- } \\
\text { Bachelor in Agroforestry } \\
\text { Technology (DAFT-BAFT) }\end{array}$ & Respondent \\
\hline $\begin{array}{ll}\text { 2. } & \text { Agusan del Sur State } \\
\text { College of Agriculture } \\
\text { and Technology } \\
\text { (ASSCAT) }\end{array}$ & State college & BSAF & Non-respondent \\
\hline $\begin{array}{l}\text { 3. Aklan State University } \\
\text { (ASU) }\end{array}$ & State university & $\begin{array}{l}\text { Agroforestry as a core } \\
\text { course in other degree } \\
\text { program }\end{array}$ & Respondent \\
\hline $\begin{array}{ll}\text { 4. } & \text { Benguet State University } \\
\text { (BSU) }\end{array}$ & State university & $\begin{array}{l}\text { BSA-AF } \\
\text { BSF-AF } \\
\text { Certificate/Diploma in } \\
\text { Agroforestry }\end{array}$ & Non-respondent \\
\hline $\begin{array}{l}\text { 5. Bicol University College } \\
\text { of Agriculture and } \\
\text { Forestry (BUCAF) }\end{array}$ & State university & BSF-AF & Non-respondent \\
\hline $\begin{array}{l}\text { 6. Cagayan State University } \\
\text { (CSU) }\end{array}$ & State university & BSA-AF & Non-respondent \\
\hline $\begin{array}{l}\text { 7. Camarines Sur State } \\
\text { Agricultural College } \\
\text { (CSSAC) }\end{array}$ & State college & BSAF & Respondent \\
\hline $\begin{array}{ll}\text { 8. } & \text { Catanduanes State } \\
& \text { College (CSC) } \\
\end{array}$ & State college & BSA-AF & Non-respondent \\
\hline $\begin{array}{l}\text { 9. Central Mindanao } \\
\text { University (CMU) }\end{array}$ & State university & $\begin{array}{l}\text { Agroforestry as a core } \\
\text { course in other degree } \\
\text { program }\end{array}$ & Respondent \\
\hline $\begin{array}{l}\text { 10. Central Visayas State } \\
\text { College of Agriculture, } \\
\text { Forestry and Technology } \\
\text { (CVSCAFT) }\end{array}$ & State college & BSAF & Respondent \\
\hline $\begin{array}{l}\text { 11. Don Mariano Marcos } \\
\text { Memorial State } \\
\text { University (DMMMSU) }\end{array}$ & State university & $\begin{array}{l}\text { BSAF } \\
\text { MSAF }\end{array}$ & Respondent \\
\hline $\begin{array}{l}\text { 12. Ifugao State College of } \\
\text { Agriculture and Forestry } \\
\text { (ISCAF) }\end{array}$ & State college & $\begin{array}{l}\text { BSAF } \\
\text { Certificate/Diploma in } \\
\text { Agroforestry }\end{array}$ & Respondent \\
\hline $\begin{array}{l}\text { 13. Iloilo State College of } \\
\text { Fisheries (ISCOF) }\end{array}$ & State college & BAFE & Non-respondent \\
\hline $\begin{array}{l}\text { 14. Isabela State University } \\
\text { (ISU) }\end{array}$ & State university & $\begin{array}{l}\text { Agroforestry as a core } \\
\text { course and thesis topic in } \\
\text { other degree programs }\end{array}$ & Respondent \\
\hline $\begin{array}{l}\text { 15. Kalinga Apayao State } \\
\text { College (KASC) }\end{array}$ & State college & BSAF & Respondent \\
\hline $\begin{array}{l}\text { 16. Mariano Marcos State } \\
\text { University }\end{array}$ & State university & MSAF in gradual phase out & Non-respondent \\
\hline $\begin{array}{l}\text { 17. Mindoro State College of } \\
\text { Agriculture and } \\
\text { Technology (MinSCAT) }\end{array}$ & State college & BSAF & Respondent \\
\hline $\begin{array}{l}\text { 18. Mindanao State } \\
\text { University (MSU) }\end{array}$ & State university & BSF-AF & Respondent \\
\hline 19. Misamis Oriental State & State college & Diploma in Agroforestry & Respondent \\
\hline
\end{tabular}




\begin{tabular}{|c|c|c|c|c|}
\hline & Academic institution & Classification & $\begin{array}{l}\text { Agroforestry curricula } \\
\text { being offered }\end{array}$ & Remarks \\
\hline & $\begin{array}{l}\text { College of Agriculture } \\
\text { and Technology } \\
\text { (MOSCAT) }\end{array}$ & & $\begin{array}{l}\text { Technology-Bachelor in } \\
\text { Agroforestry Technology } \\
\text { (DAFT-BAFT( (in gradual } \\
\text { phase out) } \\
\text { BSAF }\end{array}$ & \\
\hline & $\begin{array}{l}\text { Mountain Province State } \\
\text { Polytechnic College } \\
\text { (MPSPC) }\end{array}$ & State college & $\begin{array}{l}\text { Diploma in Agroforestry; } \\
\text { BSF-AF }\end{array}$ & Non-respondent \\
\hline & $\begin{array}{l}\text { Negros State College of } \\
\text { Agriculture (NSCA) }\end{array}$ & State college & BSA-AF & Respondent \\
\hline & $\begin{array}{l}\text { Northern Mindanao State } \\
\text { Institute of Science and } \\
\text { Technology } \\
\text { (NORMISIST) }\end{array}$ & State college & $\begin{array}{l}\text { BSAFE in gradual phase } \\
\text { out; BSAF }\end{array}$ & Non-Respondent \\
\hline & $\begin{array}{l}\text { Nueva Vizcaya State } \\
\text { University (NVSU) }\end{array}$ & State university & $\begin{array}{l}\text { BSAF } \\
\text { Diploma in Agroforestry }\end{array}$ & Respondent \\
\hline & $\begin{array}{l}\text { Occidental Mindoro } \\
\text { National College } \\
\text { (OMNC) }\end{array}$ & State college & BSA-AF & Non-respondent \\
\hline & $\begin{array}{l}\text { Pampanga Agricultural } \\
\text { College (PAC) }\end{array}$ & State college & BSAF & Respondent \\
\hline & $\begin{array}{l}\text { Quirino State College } \\
\text { (QSC) }\end{array}$ & State college & BSAF & Non-respondent \\
\hline & $\begin{array}{l}\text { Southern Philippines } \\
\text { Agribusiness, Marine and } \\
\text { Aquatic School of } \\
\text { Technology (SPAMAST) }\end{array}$ & State college & BSAF & Respondent \\
\hline 28. & $\begin{array}{l}\text { Surigao del Norte } \\
\text { College of Agriculture } \\
\text { and Technology } \\
\text { (SNCAT) }\end{array}$ & $\begin{array}{l}\text { TESDA- } \\
\text { supervised }\end{array}$ & $\begin{array}{l}\text { Diploma in Agroforestry } \\
\text { BSAF in phase out }\end{array}$ & Respondent \\
\hline 29. & $\begin{array}{l}\text { University of the } \\
\text { Philippines Los Banos } \\
\text { (UPLB) }\end{array}$ & State university & $\begin{array}{l}\text { Agroforestry as a core } \\
\text { course in other degree } \\
\text { programs }\end{array}$ & Respondent \\
\hline & $\begin{array}{l}\text { University of Rizal } \\
\text { System (URS) }\end{array}$ & State university & $\begin{array}{l}\text { Diploma in Agroforestry; } \\
\text { BSF-AF }\end{array}$ & Respondent \\
\hline & $\begin{array}{l}\text { Western Mindanao State } \\
\text { University (WMSU) }\end{array}$ & State university & BSA-Af & Non-respondent \\
\hline & $\begin{array}{l}\text { Visayas State University } \\
\text { (VSU) }\end{array}$ & State university & $\begin{array}{l}\text { Agroforestry as a core } \\
\text { course or thesis topic in } \\
\text { other degree programs }\end{array}$ & Respondent \\
\hline & $\begin{array}{l}\text { Western Visayas College } \\
\text { of Science and } \\
\text { Technology (WVCST) }\end{array}$ & State college & BSA-AF; BSAF & Respondent \\
\hline & $\begin{array}{l}\text { Wesleyan University- } \\
\text { Philippines (WU-P) }\end{array}$ & Private & BSAF in gradual phase out & Non-respondent \\
\hline
\end{tabular}




\section{WORKING PAPERS IN THIS SERIES}

2005

1. Agroforestry in the drylands of eastern Africa: a call to action

2. Biodiversity conservation through agroforestry: managing tree species diversity within a network of community-based, nongovernmental, governmental and research organizations in western Kenya.

3. Invasion of prosopis juliflora and local livelihoods: Case study from the Lake Baringo area of Kenya

4. Leadership for change in farmers organizations: Training report: Ridar Hotel, Kampala, 29th March to 2nd April 2005.

5. Domestication des espèces agroforestières au Sahel : situation actuelle et perspectives

6. Relevé des données de biodiversité ligneuse: Manuel du projet biodiversité des parcs agroforestiers au Sahel

7. Improved land management in the Lake Victoria Basin: TransVic Project's draft report.

8. Livelihood capital, strategies and outcomes in the Taita hills of Kenya

9. Les espèces ligneuses et leurs usages: Les préférences des paysans dans le Cercle de Ségou, au Mali

10. La biodiversité des espèces ligneuses: Diversité arborée et unités de gestion du terroir dans le Cercle de Ségou, au Mali

11. Bird diversity and land use on the slopes of Mt. Kilimanjaro and the adjacent plains, Tanzania

12. Water, women and local social organization in the Western Kenya Highlands

13. Highlights of ongoing research of the World Agroforestry Centre in Indonesia

14. Prospects of adoption of tree-based systems in a rural landscape and its likely impacts on carbon stocks and farmers' welfare: The FALLOW Model Application in Muara Sungkai, Lampung, Sumatra, in a 'Clean Development Mechanism' context

15. Equipping integrated natural resource managers for healthy agroforestry landscapes.

16. Are they competing or compensating on farm? Status of indigenous and exotic tree species in a wide range of agro-ecological zones of Eastern and Central Kenya, surrounding Mt. Kenya.

17. Agro-biodiversity and CGIAR tree and forest science: approaches and examples from Sumatra.

18. Improving land management in eastern and southern Africa: A review of polices.

19. Farm and household economic study of Kecamatan Nanggung, Kabupaten Bogor, Indonesia: A socio-economic base line study of agroforestry innovations and livelihood enhancement.

20. Lessons from eastern Africa's unsustainable charcoal business.

21. Evolution of RELMA's approaches to land management: Lessons from two decades of research and development in eastern and southern Africa

22. Participatory watershed management: Lessons from RELMA's work with farmers in eastern Africa.

23. Strengthening farmers' organizations: The experience of RELMA and ULAMP.

24. Promoting rainwater harvesting in eastern and southern Africa. 
25. The role of livestock in integrated land management.

26. Status of carbon sequestration projects in Africa: Potential benefits and challenges to scaling up.

27. Social and Environmental Trade-Offs in Tree Species Selection: A Methodology for Identifying Niche Incompatibilities in Agroforestry [Appears as AHI Working Paper no. 9]

28. Managing tradeoffs in agroforestry: From conflict to collaboration in natural resource management. [Appears as AHI Working Paper no. 10]

29. Essai d'analyse de la prise en compte des systemes agroforestiers pa les legislations forestieres au Sahel: Cas du Burkina Faso, du Mali, du Niger et du Senegal.

30. Etat de la recherche agroforestière au Rwanda etude bibliographique, période 19872003

31. Science and technological innovations for improving soil fertility and management in Africa: A report for NEPAD's Science and Technology Forum.

32. Compensation and rewards for environmental services.

33. Latin American regional workshop report compensation.

34 Asia regional workshop on compensation ecosystem services.

35 Report of African regional workshop on compensation ecosystem services.

36 Exploring the inter-linkages among and between compensation and rewards for ecosystem services CRES and human well-being

37 Criteria and indicators for environmental service compensation and reward mechanisms: realistic, voluntary, conditional and pro-poor

38 The conditions for effective mechanisms of compensation and rewards for environmental services.

39 Organization and governance for fostering Pro-Poor Compensation for Environmental Services.

40 How important are different types of compensation and reward mechanisms shaping poverty and ecosystem services across Africa, Asia \& Latin America over the Next two decades?

41. Risk mitigation in contract farming: The case of poultry, cotton, woodfuel and cereals in East Africa.

42. The RELMA savings and credit experiences: Sowing the seed of sustainability

43. Yatich J., Policy and institutional context for NRM in Kenya: Challenges and opportunities for Landcare.

44. Nina-Nina Adoung Nasional di So! Field test of rapid land tenure assessment (RATA) in the Batang Toru Watershed, North Sumatera.

45. Is Hutan Tanaman Rakyat a new paradigm in community based tree planting in Indonesia?

46. Socio-Economic aspects of brackish water aquaculture (Tambak) production in Nanggroe Aceh Darrusalam.

47. Farmer livelihoods in the humid forest and moist savannah zones of Cameroon.

48. Domestication, genre et vulnérabilité : Participation des femmes, des Jeunes et des catégories les plus pauvres à la domestication des arbres agroforestiers au Cameroun.

49. Land tenure and management in the districts around Mt Elgon: An assessment presented to the Mt Elgon ecosystem conservation programme. 
50. The production and marketing of leaf meal from fodder shrubs in Tanga, Tanzania: A pro-poor enterprise for improving livestock productivity.

51. Buyers Perspective on Environmental Services (ES) and Commoditization as an approach to liberate ES markets in the Philippines.

52. Towards Towards community-driven conservation in southwest China: Reconciling state and local perceptions.

53. Biofuels in China: An Analysis of the Opportunities and Challenges of Jatropha curcas in Southwest China.

54. Jatropha curcas biodiesel production in Kenya: Economics and potential value chain development for smallholder farmers

55. Livelihoods and Forest Resources in Aceh and Nias for a Sustainable Forest Resource Management and Economic Progress.

56. Agroforestry on the interface of Orangutan Conservation and Sustainable Livelihoods in Batang Toru, North Sumatra.

\section{8}

57. Assessing Hydrological Situation of Kapuas Hulu Basin, Kapuas Hulu Regency, West Kalimantan.

58. Assessing the Hydrological Situation of Talau Watershed, Belu Regency, East Nusa Tenggara.

59. Kajian Kondisi Hidrologis DAS Talau, Kabupaten Belu, Nusa Tenggara Timur.

60. Kajian Kondisi Hidrologis DAS Kapuas Hulu, Kabupaten Kapuas Hulu, Kalimantan Barat.

61. Lessons learned from community capacity building activities to support agroforest as sustainable economic alternatives in Batang Toru orang utan habitat conservation program (Martini, Endri et al.)

62. Mainstreaming Climate Change in the Philippines.

63. A Conjoint Analysis of Farmer Preferences for Community Forestry Contracts in the Sumber Jaya Watershed, Indonesia.

64. The Highlands: A shower water tower in a changing climate and changing Asia.

65. Eco-Certification: Can It Deliver Conservation and Development in the Tropics?

66. Designing ecological and biodiversity sampling strategies. Towards mainstreaming climate change in grassland management.

67. Participatory Poverty and Livelihood Assessment Report, Kalahan, Nueva Vizcaya, the Philippines

68. An Assessment of the Potential for Carbon Finance in Rangelands

69. ECA Trade-offs Among Ecosystem Services in the Lake Victoria Basin.

70. Le business plan d'une petite entreprise rurale de production et de commercialisation des plants des arbres locaux. Cas de quatre pépinières rurales au Cameroun.

71. Les unités de transformation des produits forestiers non ligneux alimentaires au Cameroun. Diagnostic technique et stratégie de développement Honoré Tabuna et Ingratia Kayitavu.

72. Les exportateurs camerounais de safou (Dacryodes edulis) sur le marché sous régional et international. Profil, fonctionnement et stratégies de développement.

73. Impact of the Southeast Asian Network for Agroforestry Education (SEANAFE) on agroforestry education capacity.

74. Setting landscape conservation targets and promoting them through compatible land use in the Philippines. 
75. Review of methods for researching multistrata systems.

76. Study on economical viability of Jatropha curcas L. plantations in Northern Tanzania Assessing farmers' prospects via cost-benefit analysis

77. Cooperation in Agroforestry between Ministry of Forestry of Indonesia and International Center for Research in Agroforestry

78. "China's bioenergy future. an analysis through the Lens if Yunnan Province

79. Land tenure and agricultural productivity in Africa: A comparative analysis of the economics literature and recent policy strategies and reforms

80. Boundary organizations, objects and agents: linking knowledge with action in agroforestry watersheds

81. Reducing emissions from deforestation and forest degradation (REDD) in Indonesia: options and challenges for fair and efficient payment distribution mechanisms

82. Mainstreaming Climate Change into Agricultural Education: Challenges and Perspectives.

83. Challenging Conventional mindsets and disconnects in Conservation: the emerging role of eco-agriculture in Kenya's Landscape Mosaics.

84. Lesson learned RATA garut dan bengkunat: suatu upaya membedah kebijakan pelepasan kawasan hutan dan redistribusi tanah bekas kawasan hutan.

85. The emergence of forest land redistribution in Indonesia.

86. Commercial opportunities for fruit in Malawi.

87. Status of fruit production processing and marketing in Malawi.

88. Fraud in tree science.

89. Trees on farm: analysis of global extent and geographical patterns of agroforestry

90. The springs of Nyando: water, social organization and livelihoods in Western Kenya.

91. Building cpacity toward region-wide curriculum and teaching materials development in agroforestry education in Southeast Asia.

92. Overview of Biomass Energy Technology in Rural Yunnan.

93. A Pro-Growth Pathway for Reducing Net GHG Emissions in China

94. Analysis of local livelihoods from past to present in the central Kalimantan Ex-Mega Rice Project area

95. Constraints and options to enhancing production of high quality feeds in dairy production in Kenya, Uganda and Rwanda 

The World Agroforestry Centre is an autonomous, non-profit research organization whose vision is a rural transformation in the developing world where smallholder households strategically increase their use of trees in agricultural landscapes to improve their food security, nutrition, income, health, shelter, energy resources and environmental sustainability. The Centre generates science-base knowledge about the diverse role that trees play in agricultural landscapes, and uses its research to advance policies and practices that benefit the poor and the environment.

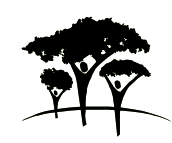

United Nations Avenue, Gigiri - PO Box 30677 - 00100 Nairobi, Kenya Tel: +254 207224000 or via USA +1 6508336645 Fax: +254207224001 or via USA +16508336646 Southeast Asia Regional Programme - Sindang Barang, Bogor 16680 PO Box161 Bogor 16001, Indonesia Tel: +62 251625415 - Fax: +62 251625416 www.worldagroforestry.org 